\title{
ROLE OF IMPROVED CLOVERS IN NON-ARABLE PASTURE RENEWAL IN MID-CANTERBURY
}

S.M. Francis' and N.C. Merrick Winchmore Irrigation Research Station, MAFTech, Ashburton

Abstract

Trials under sheep and dairy cow grazing in mid Canterbury examined the effectiveness of including new white clover cultivars with ryegrass in a non-arable (spray, top-cultivate and drill) pasture renewal. Five weeks after sowing, $13 \%$ of white clover plants had originated from regrowing stolons in the sheep pasture; in dairy pasture the figure was over $50 \%$.

Initially including a white clover cultivar increased total dry matter yield. However after 3 years there was no difference in total dry matter yield from plots sown with ryegrass but no clover. 'Grasslands Kopu' white clover outproduced 'Grasslands Huia' by only $4 \%$ and $1 \%$ in dairy and sheep pastures respectively and had a slightly greater white clover content. Control plots initially had a lower clover percentage than the sown cultivars. but by the third year it tended to be greater.

The greater average length of leaflets in Kopu plots indicated that the cultivar was present throughout both trials.

It is suggested that the inclusion of white clover in non-arable pasture renewal will give economic returns only if seed costs are low.

Keywords: 'Grasslands Kopu', 'Grasslands Huia', white clover, pasture renewal, irrigation

\section{INTRODUCTION}

Many farmers in mid Canterbury renovate old border-strip irrigated pastures by spraying and direct-drilling, with some surface cultivation if rebordering is necessary. Often existing white clover stolons are not killed by this practice, while the soil may also contain a heavy load of buried seed, giving rise to a population of resident white clover in the new sward. On a Waikato dairy farm, Ledgard et al. (1988) found poor establishment of white clover cultivars direct-drilled into hardgrazed pastures because of competition from resident white clovers. Establishment was improved by prior spraying with glyphosate and dicamba, but not by rotary cultivation which increased the germination of buried seed.

'Grasslands Huia' white clover is the main cultivar used with ryegrass in New Zealand's pastures. The new cultivar 'Grasslands Kopu' is a large-leaved white clover with an erect growth habit. Its Mediterranean parentage. suggests good winter and early spring growth in warmer climates and good growth in summer when moisture is sufficient. Trials in Northland and Manawatu under sheep grazing found Kopu to have up to $20 \%$ superior clover dry matter production to Huia (Van den Bosch et al. 1986; Brock 1988). Under dairy grazing at Taupo and in Manawatu, Moloney et $a /$. (1988) found there was no difference in the annual dry matter production but autumn and winter yields were significantly greater from Kopu than from pastures containing Huia. In Waikato under dairying, Kopu pastures provided a higher clover content than Huia pastures with total herbage production similar for both (Ledgard et al. 1988).

Two trials investigated the production of Kopu and Huia white clovers sown with Ellett ryegrass into sprayed and top-cultivated old pasture on a sheep and a dairy farm. Control areas sown with ryegrass but no clover were used to assess the contribution of resident white clover.

${ }^{1}$ Present address: PO Box 24, Lincoln 


\section{MATERIALS AND METHODS}

The trials were sown in March 1984 on border-strip irrigated Lismore stony silt loam soils. At both sites areas within larger paddocks of permanent pasture were sprayed with $3 \mathrm{l} / \mathrm{ha}$ glyphosate and rotary cultivated several times before sowing. The two treatments, Kopu and Huia white clover ( $3 \mathrm{~kg}$ seed/ha) were sown with Ellett ryegrass $(18 \mathrm{~kg} / \mathrm{ha})$ in $8 \times 10 \mathrm{~m}$ plots in a randomised block design with 4 replicates. Additional plots at each end of the trial, sown with ryegrass alone, were used to study the resident white clover population.

Five weeks after sowing numbers of white clover plants were counted in two $0.25 \mathrm{~m}^{2}$ quadrats per plot. The number of 'resident' plants (regrowth from clover stolon) and seedlings were recorded separately.

Pastures were irrigated when soil moisture declined to approximately $20 \%$ by weight. All plots were grazed together for a duration of less than 24 hours. Dry matter (DM) production before and after each grazing was measured indirectly using the pasture probe to determine herbage mass. The probe was calibrated for each measurement by cutting ten $0.25 \mathrm{~m}^{2}$ quadrats to ground level. At each grazing, botanical composition was determined from 5 samples per plot cut to ground level. To check that Kopu was still present, the length of the middle leaflet was measured on 10 randomly selected clover leaves per plot. Pasture production measurements were not taken from the dairy pasture in the establishment year.

\section{RESULTS AND DISCUSSION}

For the sheep pasture the number of Huia-and Kopu white clover seedlings emerging did not differ. For the dairy pasture, Kopu had half the number of seedlings of Huia (Table 1). Seedlings in the control were very few, indicating that only few buried seeds had germinated at both sites. Regrowth from existing white clover stolons accounted for $13 \%$ of total plant numbers in the sheep pastures and for $47 \%$ of total white clover plants in Huia and $74 \%$ in Kopu plots in the dairy pastures (Table 1). This illustrates the difficulty of trying to introduce new white clover cultivars into a pasture without continued cultivation to kill stolons from resident plants and plants from germinating buried seed.

Averaged over the duration of the trials, Kopu produced only slightly more (nonsignificant) total DM than Huia (Table 2). Although Kopu sown plots tended to have a greater white clover content than Huia pastures, in agreement with Ledgard et al. 1988, the differences were small not statistically significant (Table 3).

The control plots yielded 83,98 and $100 \%$ of the total annual DM of Huia sown sheep pasture for the three years, and 76 and $98 \%$ for the second and third years in dairy pasture. There were no consistent differences between the cultivars or control plots in seasonal distribution of DM production. In the first year of measurement, control plots had a lower clover percentage than the plots sown with a clover cultivar, but by the last year of the trials the unsown plots tended to have a higher white clover content (Table 3). This indicates how the resident white clover population can re-establish itself after disruption by spraying and top-cultivation during non-arable pasture renewal.

Most of the North Island trials have shown little difference in total DM production but greater white clover yield from Kopu than from Huia pastures (Van den Bosch et al. 1986; Brock 1988). In this trial there was initially an advantage in sowing a white clover cultivar at both sites, but the differences between the cultivars were small. There are probably two reasons for this:

(1) In mid Canterbury, with cool winter and late-spring temperatures, Kopu could not express its genetic potential for higher DM production than Huia, 
(2) Competition from the resident white clover, well adapted to this environment, did not allow Kopu to develop as a major component of the sward.

Table 1: Number of white clover seedlings and regrowth of white clover stolons 5 weeks after sowing (i) under sheep grazing

\begin{tabular}{rcc} 
& \multicolumn{2}{c}{ White clover plants $/ \mathbf{m}^{\star}$} \\
Huia & Seedlings & Regrowth \\
Kopu & 186 & 28 \\
Control & 183 & 25 \\
Isd $(\rho<0.05)$ & 14 & 26 \\
& 71 & 20
\end{tabular}

(ii) under dairy cow grazing

$\begin{array}{rrr}\text { Huia } & 40 & 36 \\ \text { Kopu } & 19 & 53 \\ \text { Control } & 4 & 34 \\ \text { Isd }(\rho<0.05) & 27 & 30\end{array}$

- for comparison between Kopu and Huia. Isd for comparison of cultivars with the control $=$ Isd $\times 1.2$

Table 2: Total annual dry matter production ( $t / h a)$

(i) under sheep grazing

$\begin{array}{lcccr} & \text { Year } 1 & \text { Year } 2 & \text { Year 3 } & \text { Mean } \\ \text { Huia } & 11.5 & 18.7 & 16.9 & 15.7 \\ \text { Kopu } & 12.4 & 18.5 & 16.5 & 15.6 \\ \text { Isd }(\rho<0.05) & 1.5 & 4.2 & 2.8 & 1.8\end{array}$

(ii) under dairy cow grazing

\begin{tabular}{lrrrr} 
Huia & - & 12.4 & 12.6 & 12.5 \\
Kopu & & 12.6 & 13.3 & 13.0 \\
Isd $(p<0.05)$ & - & 4.4 & 4.2 & 3.6 \\
\hline
\end{tabular}

Table 3: Average annual clover content (\%)

(i) under sheep grazing

\begin{tabular}{|c|c|c|c|}
\hline \multicolumn{4}{|l|}{ (I) under sheep grazing } \\
\hline & Year 1 & Year 2 & Year 3 \\
\hline Huia & 19 & 13 & 4 \\
\hline Kopu & 22 & 16 & 5 \\
\hline Control & 17 & 17 & 7 \\
\hline Isd $(0<0.05)$ & 18 & 9 & 6 \\
\hline
\end{tabular}

(ii) under dairy cow grazing

\begin{tabular}{|c|c|c|c|}
\hline Huia & & 18 & 13 \\
\hline Kopu & & 18 & 14 \\
\hline Control & & 16 & 19 \\
\hline Isd $(p<0.05)$ & - & 9 & 4 \\
\hline
\end{tabular}

Table 4: Average length of the middle leaflet $(\mathrm{mm})$ for Huia, Kopu and control Plots

(i) under sheep grazing

$\begin{array}{rccc} & \text { Year } 1 & \text { Year } 2 & \text { Year } 3 \\ \text { Huia } & 11.3 & 13.6 & 12.0 \\ \text { Kopu } & 12.7 & 159 & 13.0 \\ \text { Control } & 11.4 & 13.9 & 11.6 \\ \text { Isd }(p<0.05) & 0.6 & 1.4 & 1.0\end{array}$

ii) $>$,, grazing

\begin{tabular}{rcc} 
Hula & 14.1 & 12.9 \\
Kopu & 16.6 & 13.1 \\
Control & 16.2 & 13.2 \\
$\mathrm{Sc}(0<0.05)$ & 0.7 & 0.3 \\
\hline
\end{tabular}


The greater average leaflet length in Kopu plots (Table 4) throughout the trials showed that at least some Kopu plants were present. However, as these differences became less each year of the trial, it appears that the density of Kopu decreased, more so under dairy cow than sheep grazing. This may be due to competition from resident white clover or a lack of persistence by Kopu in these intensively grazed, irrigated mid Canterbury pastoral systems. Leaflets from Huia and control plots were the same length throughout both trials, indicating that the resident white clover was probably derived from an original Huia sowing.

There may initially be benefits in total DM production from including white clover in the seed mixture for non-arable pasture renewal, but in the longer term, pastures will probably not suffer from the absence of a new white clover cultivar.

\section{Acknowledgements}

Thanks to Cynthia Swaine and Brian Sandrey for assisting in pasture measurements and David Baird for help with data processing.

\section{References}

Brock, J.L. 1988. Evaluation of New Zealand bred white clover cultivars under rotational grazing and set stocking with sheep. Proceedings NZ Grasslands Association 49: 203-206.

Ledgard, S.F.; Brier, G.J.; Watson, R.N. 1988. New clover cultivars for Waikato dairy pasture: establishment, production and nitrogen fixation during the first year. Proceedings NZ Grassland Association 49: 207-I 1.

Moloney, S.C.; Hay, R.J.M.; Lancashire. J.A. 1988. The performance of Grasslands Kopu white clover on two daily farms. Proceedings NZ Grassland Association 49: 97-100.

Van den Bosch. J.: Lancashire, J.A. Cooper, B.M.; Lyons, T.B.; Williams, W.M. 1986. G18 white clover — a new cultivar for lowland pastures. Proceedings NZ Grassland Association 47: 173-77. 